\title{
ANALISA GOOD CORPORATE GOVERNANCE, PENGARUHNYA PADA FINANCIAL PERFORMANCE DI PERUSAHAAN YANG TERDAFTAR PADA CORPORATE GOVERNANCE PERCEPTION INDEX (CGPI)
}

\author{
Angela Merici Biuty ${ }^{1}$, Wijaya Triwacananingrum ${ }^{2}$ \\ angelamericibiuty@gmail.com \\ wijaya.tri@uph.edu \\ Universitas Pelita Harapan \\ Lippo Karawaci-Tangerang \\ Telp. 081367970200
}

\begin{abstract}
Abstrak
Tulisan ini meneliti dengan menganalisa Good Corporate Governance (GCG) serta pengaruhnya pada financial performance perusahaan dengan variabel independen skor CGPI (Corporate Governance Perception Index) dipakai sebagai deteksi diterapkannya GCG, sedangkan variabel dependen kinerja keuangan menggunakan rasio profitabilitas yang di proksikan dalam Return on Equity (ROE), Net Profit Margin (NPM), dan Earning's Per Share (EPS). Variabel control dalam penelitian ini yaitu size dan leverage.

Penelitian ini menggunakan sampel yang diperoleh dengan purposive sampling, dimana peneliti menetapkan kriteria penerapan GCG oleh perusahaan-perusahaan yang telah dipilih serta yang terdaftar di Bursa Efek Indonesia (BEI) selama 6 tahun.

Laporan CGPI tahun 2011-2016 dan financial report tahun 2011-2016 merupakan data yang diambil untuk di analisa dalam penelitian ini. Sedangkan dalam menguji hipotesis menggunakan metode statistik melalui analisis regresi berganda. Analisa data penelitian ini dilengkapi dengan uji statistik deskriptif, uji normalitas, uji multikolinearitas, uji autokorelasi, dan uji heteroskedastisitas, uji koefisien determinasi, uji-F, dan uji-t.

Penelitian ini menunjukkan hasil: (1) Penerapan GCG tidak berpengaruh positif pada kinerja keuangan perusahaan yang dinyatakan dengan ROE, (2) Penerapan GCG tidak berngaruh positif terhadap kinerja keuangan perusahaan yang dinyatakan dalam NPM, dan (3) Penerapan GCG berpengaruh positif terhadap kinerja keuangan perusahaan yang dinyatakan dalam EPS.
\end{abstract}

Kata Kunci: Good Corporate Governance (GCG), Return on Equity (ROE), Net Profit Margin (NPM), dan Earning's Per Share (EPS), Corporate Governance Perception Index (CGPI)

\section{Pendahuluan}

Kinerja keuangan perusahaan dapat diartikan sebagai indikasi pencapaian perusahaan dalam suatu periode tertentu sebagai hasil kinerja selama periode tersebut. Untuk itu penilaian terhadap suatu perusahaan sangat penting bagi perusahaan karena menyangkut pihak luar perusahaan yang memiliki kepentingan bagi perusahaan yang bersangkutan. Saat ini tingkat korupsi di dunia masih cenderung tinggi dikarenakan semakin pesatnya perkembangan bisnis sehingga perusahaan melakukan berbagai upaya untuk dapat bersaing. Sudah banyak perusahaanperusahaan yang menerapkan sistem good corporate governance, tetapi masih banyak pula perusahaan yang masih lemah dan kurang efisien dalam melakukan tata kelola di perusahaannya, sehingga tidak sesuai dengan apa yang menjadi tujuan perusahaan.

Menurut Priantara (2017), muncul isu terjadinya fraud akuntansi sejak awal triwulan kedua 2017 di British Telecom yang berdampak kepada akuntan publiknya, yaitu Price Waterhouse Coopers (PwC) sebagai Kantor Akuntan Publik ini termasuk dalam The Bigfour. Fraud dilakukan dengan cara menaikkan pendapatan perusahaan dengan melakukan perpanjangan kontrak tidak sebenarnya dan juga invoice-invoice nya, serta adanya transaksi-transaksi yang palsu dengan vendor. Dampak dari kasus ini mengakibatkan reputasi kantor akuntan publik tersebut tercemar, dan memberi 
akibat buruk pada profesi akuntan publik, serta dapat merusak atau menurunkan value perusahaan. Kasus ini merupakan salah satu contoh bahwa laporan keuangan yang telah audited-pun tidak semua dapat benar-benar terpercaya (audited tetapi tidak terjamin). Salah satu faktor yang menyebabkan terjadinya fraud akuntansi adalah karena kurang baiknya penerapan good corporate governance di perusahaanya.

Menurut Lestari dan Wirawati (2016), penerapan good corporate governance yang lemah dalam sebuah perusahaan dapat memberikan peluang bagi pihak-pihak tertentu untuk memaksimalkan kepentingan bagi dirinya sendiri yang pada akhirnya akan merugikan perusahaan. Untuk dapat memperbaiki nilai perusahaan, maka perusahaan-perusahaan di Indonesia harus dapat memperbaiki tata kelola perusahaannya.

Dengan diterapkannya konsep good corporate governance pada perusahaan di Indonesia, diharapkan dapat mencegah adanya kesalahan yang timbul dalam mengambil keputusan dan tindakantindakan yang hanya berorientasi pada pihak intern sendiri yang akibatnya hanya bertujuan akan meningkatkan nilai yang nampak pada kinerja perusahaan dan dapat mempengaruhi hubungan dengan peningkatan citra perusahaan yang dapat menjadi pengaruh bagi kepercayaan para investor dalam berinvestasi pada perusahaan tersebut. Diperlukan manajemen yang baik untuk mencapai hal tersebut dalam mengelola perusahaan sehingga kinerja keuangan perusahaan akan baik pula.

Banyaknya penelitian mengenai good corporate governance, hal ini menggambarkan kalau variabel good corporate governance merupakan suatu hal yang penting dalam menilai perusahaan yang sehubungan dengan kinerja keuangan suatu perusahaan.

Hasil penelitian Paradita (2009) mengungkapkan bahwa variabel good corporate governance tidak ada pengaruh secara parsial terhadap ROI, ROE, dan NPM sedangkan penerapan good corporate governance memiliki pengaruh negatif terhadap kinerja keuangan.
Dalam penelitiannya, Suparlim (2013) menggambarkan jika corporate governance dilaksanakan dengan baik di suatu perusahaan maka akan semakin meningkatkan ROA perusahaan tersebut, namun tidak memiliki pengaruh positif terhadap NPM dan Tobin's Q.

Berdasarkan beberapa penelitian diatas dalam memprediksi pengaruh good corporate governance pada kinerja keuangan perusahaan, penulis terdorong untuk melakukan penelitian dalam menguji good corporate governance yang mempengaruhi kinerja keuangan perusahaan, apakah praktek good corporate governance dapat menaikkan kinerja keuangan perusahaan.

Pada penelitian ini, penulis memilih perusahaan sampel selama enam tahun berturut-turut, dari tahun 2011-2016 telah mengikuti penerapan good corporate governance. Skor CGPI (Corporate Governance Perception Index) digunakan penulis sebagai variabel independen untuk mengukur pemeringkatan penerapan good corporate governance pada perusahaan untuk melihat seberapa baik tata kelola yang diterapkan pada perusahaan tersebut yang dapat mempengaruhi kinerja keuangan sebagai variabel dependen perusahaan yang diproksikan dalam ROE, NPM, dan EPS serta terdapat variabel kontrol yang digunakan oleh penulis yaitu size dan leverage.

Penelitian ini menggunakan pendekatan teori agensi, menurut Jumandani (2012), teori agency memaparkan terdapat hubungan positif shareholder dan manager melalui good corporate governance dalam pengelolaan perusahaan. Forum for Corporate Governance in Indonesia (FCGI, 2001) mendefinisikan good corporate governance dalam Kompasnia (2016) bahwa good corporate governance adalah Suatu peraturan yang menata hubungan antara pemegang saham, pengurus (pengelola) perusahaan, pihak kreditur, pemerintah, karyawan serta para pemangku kepentingan intern dan ekstern yang berkaitan dengan hak-hak serta kewajiban dari mereka.

Menurut Organization for Economic Corporation and Development (OECD, 
2016) dalam Kompasnia (2016) yang telah mengembangkan prinsip-prinsip good corporate governance, dimana prinsipprinsip utama yang perlu mendapat perhatian untuk dapat diselenggarakannya corporate governance dengan baik adalah:
1. Pertanggungjawaban /Responsibility

2. Transparansi /Transparency

3. Akuntabilitas/Accountability

4. Kesetaraan dan Kewajaran/ Fairness

5. Independensi /Independency

Tabel 1 Tahapan dan Bobot Penilaian dan Pemeringkatan CGPI

\begin{tabular}{|c|l|c|}
\hline No & \multicolumn{1}{|c|}{ Tahapan } & Bobot (\%) \\
\hline 1 & Self Assessment & 30 \\
2 & Data yang lengkap & 26 \\
3 & $\begin{array}{l}\text { Makalah- makalah yang menggambarkan } \\
\text { program serta hasil penerapan GCG sebagai }\end{array}$ & 15 \\
4 & $\begin{array}{l}\text { sebuah sistem di perusahaan } \\
\text { Observasi }\end{array}$ & 29 \\
\hline
\end{tabular}

Sumber: Laporan CGPI, 2016

Tabel 2 Norma Penilaian

\begin{tabular}{|c|c|}
\hline Skor & Kategori \\
\hline $55.00-69.99$ & Cukup Dipercaya \\
$70.00-84.99$ & Dipercaya \\
$85.00-100$ & Sangat Dipercaya \\
\hline
\end{tabular}

Sumber: Laporan CGPI, 2016

\section{Metode Penelitian}

Gambar 1 Kerangka Pemikiran Penelitian

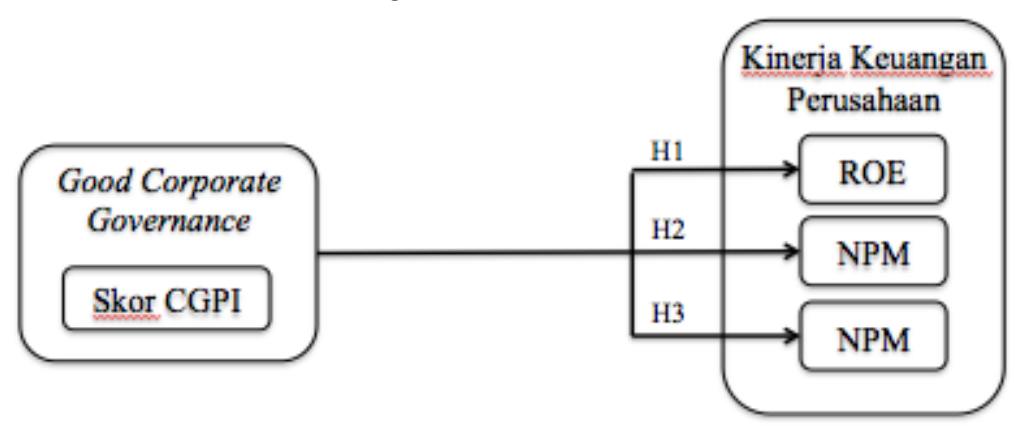

Sumber: Hasil Olah Gambar oleh Penulis, 2017

Dari kerangka berpikir tersebut di atas dikembangkan hipotesis, sehingga dapat dirumuskan hipotesis bahwa Good Corporate Governance berpengaruh positif terhadap ROE, Good Corporate Governance memiliki pengaruh positif terhadap NPM, dan Good Corporate Governance berpengaruh positif terhadap EPS.

Sampel data dari Indonesian Capital Market Directory (ICMD), juga dari laporan keuangan emiten yang dipublikasikan oleh BEI dan pada Pusat Referensi Pasar Modal (PRPM) BEI, dan data historik dari The
Indonesian Institute for Corporate Governance (IICG).

Diuji menggunakan model regresi berganda (multiple regression analysis) yang digunakan untuk melakukan uji pengaruh good corporate governance terhadap kinerja keuangan perusahaan untuk periode 2011-2016. Model empiris pada penelitian ini adalah persamaan regresi berganda, yaitu:

$$
\begin{aligned}
& \operatorname{ROE}_{\mathrm{i}, \mathrm{t}}=\alpha+\beta_{1} \mathrm{CGPI}_{\mathrm{i}, \mathrm{t}}+\beta_{2} \operatorname{Size}_{\mathrm{i}, \mathrm{t}}+\beta_{3} \operatorname{Lev}_{\mathrm{i}, \mathrm{t}}+ \\
& \mathrm{NPM}_{\mathrm{i}, \mathrm{t}}=\alpha+\beta_{1} \mathrm{CGPI}_{\mathrm{i}, \mathrm{t}}+\beta_{2} \operatorname{Size}_{\mathrm{i}, \mathrm{t}}+\beta_{3} \operatorname{Lev}_{\mathrm{i}, \mathrm{t}}+
\end{aligned}
$$


$\begin{aligned} \text { EPS }_{\mathrm{i}, \mathrm{t}}= & \alpha+\beta_{1} \mathrm{CGPI}_{\mathrm{i}, \mathrm{t}}+\beta_{2} \text { Size }_{\mathrm{i}, \mathrm{t}}+\beta_{3} \mathrm{Lev}_{\mathrm{i}, \mathrm{t}}+ \\ \varepsilon_{\mathrm{i}, \mathrm{t}} & \end{aligned}$ Dimana:

$\alpha=$ konstata

$\beta_{1}-\beta_{3}=$ koefisien regresi

CGPI =Corporate Governance Perception Index

Size = Ukuran Perusahaan

Lev $=$ leverage

$\varepsilon=$ error term atau tingkat kesalahan pendugaan dalam penelitian

$\mathrm{i}, \mathrm{t}=$ identifikasi untuk perusahaan (i) dan tahun $(\mathrm{t})$

Dengan menggunakan alat SPSS maka data tersebut diolah.

\section{Hasil dan Pembahasan}

a. Analisis Statistik Deskriptif

Return on Equity, variabel ROE terdapat nilai minimum sebesar 0,02 dan nilai maksimumnya sebesar 0,38 . Hasil tersebut menggambarkan bahwa besarnya variabel ROE perusahaan sampel ini berkisar antara 0,02 sampai 0,38 dengan nilai rata-rata sebesar 0,1584 sedangkan standar deviasi sebesar 0,07150 .

Net Profit Margin nilai minimumnya sebesar 0,02 sedangkan nilai maksimum sebesar 0,58. Hasil tersebut menggambarkan bahwa besarnya variabel NPM perusahaan sampel ini berkisar antara 0,02 sampai 0,58 dengan nilai rata-rata sebesar 0,2671 dan standar deviasi sebesar 0,16717.

Earning's Per Share memiliki nilai minimum 14,00 dan nilai maksimum sebesar 1339,00. Hasil tersebut menunjukkan bahwa besarnya variabel EPS perusahaan sampel ini berkisar antara 14,00 sampai 1339,00 dengan nilai rata-rata 445,8172 dan standar deviasi 363,49989 .

Good Corporate Governance nilai minimumnya 70,73 dan nilai maksimum 93,30. Hasil tersebut menunjukkan bahwa besarnya variabel penerapan GCG perusahaan sampel ini berkisar antara 70,73 sampai 93,30 dengan rata-rata nilai sebesar 85,2994 dan standar deviasi 4,63128 .

Size nilai minimumnya 29,44 dan nilai maksimum 34,58. Hasil tersebut menunjukkan bahwa besarnya variabel Size perusahaan sampel ini berkisar antara 29,44 sampai 34,58 dan dengan nilai rata-rata sebesar 31,9331 serta standar deviasi sebesar 1,74546.

Leverage nilai minimumnya sebesar 0,34 sedangkan nilai maksimum sebesar 11,40. Hasil tersebut menunjukkan bahwa besarnya variabel Leverage perusahaan sampel ini berkisar antara 0,34 sampai 11,40 dengan nilai rata-rata sebesar 4,0931 dan standar deviasi sebesar 3,61342.

Berdasarkan perhitungan korelasi pearson dapat disimpulkan sebagai berikut:

Korelasi variabel independen skor CGPI dan variabel kontrol size dengan nilai signifikansi sebesar $0,000<0,05$ yang berarti asosiasi kedua variabel adalah signifikan.

Korelasi variabel independen skor CGPI dan variabel kontrol leverage nilai signifikansi nya sebesar $0,001<0,05$ yang dapat diartikan asosiasi dari kedua variabel adalah signifikan.

Korelasi variabel independen skor CGPI dan variabel dependen ROE dengan nilai signifikansi sebesar 0,490 > 0,05 yang dapat diartikan asosiasi kedua variabel adalah tidak signifikan.

Korelasi variabel independen skor CGPI dan variabel dependen NPM nilai signifikansinya sebesar $0,000<0,05$ yang bearti asosiasi keda variabel adalah signifikan.

Korelasi variabel independen skor CGPI dan variabel dependen EPS memiliki nilai signifikansi sebesar 0,021 $>0,05$ yang dapat diartikan asosiasi kedua variabel adalah tidak signifikan.

Korelasi variabel kontrol size dan variabel kontrol leverage memiliki nilai signifikansi sebesar $0,000<0,05$ yang berarti asosiasi kedua variabel adalah signifikan. 
Korelasi variabel kontrol size dan variabel dependen ROE dengan nilai signifikan sebesar $0,933>0,05$ yang dapat diartikan asosiasi kedua variabel adalah tidak signifikan.

Korelasi variabel kontrol size dan variabel dependen NP nilai signifikansi sebesar $0,000<0,05$ yang dapat diartikan asosiasi kedua variabel adalah signifikan.

Korelasi variabel kontrol size dan variabel dependen EPS nilai signifikansinya sebesar $0,379>0,05$ yang berarti asosiasi kedua variabel tidak signifikan.

Korelasi variabel kontrol leverage dan variabel dependen ROE nilai signifikansinya sebesar $0,482>0,05$ yang berarti asosiasi kedua variabel adalah tidak signifikan.

Korelasi variabel kontrol leverage dan variabel dependen NPM memiliki signifikansi sebesar $0,000<0,05$ yang berarti asosiasi kedua variabel adalah signifikan.

Korelasi variabel kontrol leverage dan variabel dependen EPS memiliki nilai signifikansi sebesar $0,463>0,05$ yang berarti asosiasi kedua variabel tidak signifikan.

\section{b. Hasil Uji Normalitas}

Nilai signifikansi pada baris Asymp. Sig. (1-tailed) menggambarkan bahwa variabel independen dan variabel dependen ROE tersebar dengan normal, dimana hasil signifikansinya 0,200. Dengan kata lain, hasil signifikansi variabel dependen ROE di atas nilai signifikansi 0,05 .

Variabel dependen dan variabel independen NPM tersebar dengan normal, dimana hasil signifikansinya adalah 0,200. Dengan kata lain, hasil signifikansi variabel dependen NPM di atas nilai signifikansi 0,05 .

Variabel dependen dan variabel independen EPS tersebar dengan normal, dimana hasil signifikansinya adalah 0,200 . Dengan kata lain, hasil signifikansi variabel dependen EPS di atas nilai signifikansi 0,05 .

\section{c. Uji Multikolinearitas}

Terhadap variabel dependen ROE, interkorelasi variabel bebas nilai Tolerance di atas 0,1 dan VIF $<10$. Nilai Tolerance variabel skor CGPI sebesar 0,297 dan VIF sebesar 3,366; nilai Tolerance variabel size sebesar 0,174 dan VIF sebesar 5,740; serta nilai Tolerance variabel leverage sebesar 0,390 dan VIF sebesar 2,566. Hasil penelitian ini dapat dibuat kesimpulan bahwa tidak terjadi multikolinearitas antar variabel bebas terhadap variabel dependen ROE.

Terhadap variabel dependen NPM, hasil ini dapat dibuat kesimpulan bahwa tidak terjadi multikolinearitas antar variabel bebas terhadap variabel dependen NPM.

Terhadap variabel dependen EPS, hasil ini dapat ditarik kesimpulan bahwa tidak adanya multikolinearitas antar variabel bebas terhadap variabel dependen EPS.

\section{d. Uji Autokorelasi}

Terhadap ketiga variabel dependen ROE, NPM dan EPS menunjukkan bahwa autokorelasi sama dengan nol atau tidak terjadinya autokorelasi dalam model regresi penelitian ini.

\section{e. Uji Heterokedastisitas}

Dari hasil olah data ketiga variable dependen ini tidak terdapat heterokedastisitas.

\section{f. Uji Hipotesis}

1) Uji Koefisien Determinasi (Adjusted $R^{2}$ ) Terhadap variable dependen ROE, nilai adjusted $R^{2}$ pada tabel 4.21 sebesar 0,020 . Hal ini dapat diartikan bahwa ROE tidak dapat dijelaskan dengan menggunakan good corporate governance (CGPI) dan variabel kontrol (size dan leverage).

Terhadap variabel dependen NPM, nilai adjusted $\mathrm{R}^{2}$ adalah sebesar 0,735 dengan kata lain apabila nilainya dekat angka 1 dapat diartikan bertambah kuatnya pengaruh dari variabel independen dengan variabel dependen. Hasil tersebut menunjukkan bahwa 
variabel independen yaitu good corporate governance (CGPI) dan variabel kontrol (size dan leverage) hanya dapat menjelaskan variasi dari variabel dependen NPM 73,5\% sedangkan sisanya $(100 \%-73,5 \%=$ $26,5 \%$ ) hanya dapat dijelaskan oleh faktor-faktor lain yang bukan termasuk didalam model regresi.

Terhadap variabel dependen EPS, nilai adjusted $\mathrm{R}^{2}$ adalah sebesar 0,240 dengan kata lain masih jauh dari angka 1 yang berarti tidak cukup besar pengaruh variabel independen terhadap variabel dependen. Hasil tersebut dapat menggambarkan bahwa variabel independen yaitu good corporate governance (CGPI) dan variabel kontrol (size dan leverage) hanya dapat memaparkan variasi dari variabel dependen EPS sebesar 24\% sedangkan sisanya $(100 \%-24 \%=76 \%)$ mampu digambarkan oleh faktor-faktor lain di luar model regresi di atas.

\section{2) Uji Simultan (Uji F)}

Menurut Ghozali (2011), uji statistik F prinsipnya menggambarkan semua variabel independen/ bebas yang termasuk didalam model berpengaruh secara bersama terhadap variabel dependen/terikat.

Hasil pengujian uji $\mathrm{F}$ dengan analisis ANOVA.

Terhadap variabel dependen ROE, diketahui bahwa $\mathrm{F}$ hitung variabel dependen ROE sebesar 0,769 dengan nilai Sig. 0,520. Dari perhitungan tersebut dapat dinyatakan bahwa H1 ditolak. Dengan kata lain variabel independen yang terdiri dari skor CGPI, size, dan leverage secara bersama atau secara simultan tidak berpengaruh terhadap variabel dependen ROE.

Terhadap variabel dependen NPM, F hitung variabel dependen NPM sebesar 33,426 dengan nilai Signifikan 0,000. Dari hasil tersebut dapat dinyatakan bahwa $\mathrm{H} 2$ diterima, dengan kata lain variabel independen yang terdiri dari skor CGPI, size, dan leverage secara simultan berpengaruh terhadap variabel dependen NPM.
Terhadap variabel dependen EPS, F hitung variabel dependen EPS sebesar 4,693 dengan nilai Signifikan sebesar. 0,008 . Dari hasil perhitungan tersebut dapat dinyatakan bahwa H3 diterima, dengan kata lain variabel independen yang terdiri dari skor CGPI, size, dan leverage secara simultan dapat mempengaruhi variabel dependen EPS.

\section{Pembahasan}

a. Pengaruh GCG Terhadap Kinerja Keuangan Perusahaan (ROE)

Berdasarkan hasil penelitian dari persamaan regresi untuk hipotesis pertama secara parsial dapat dikatakan bahwa analisa good corporate governance tidak berpengaruh positif pada kinerja keuangan perusahaan (yang diproksikan dengan ROE). Hasil ini ditunjukkan dari hasil penelitian yang menghasilkan nilai signifikansi sebesar $0,955>0,05$. Hasil perhitungan ini memperlihatkan kurangnya transparansi di dalam perusahaan untuk mengungkapkan kinerja keuangan perusahaannya, sehingga penerapan good corporate governance belum diterapkan sebaik mungkin. Salah satu faktor utamanya adalah persaingan antar perusahaan yang semakin ketat sehingga perusahaan-perusahaan tersebut masih takut untuk mengungkapkan kinerja keuangan perusahaan secara transparan. Hal ini dapat meminimalkan tingkat kepercayaan bagi para calon investor yang ingin menanamkan modal ke perusahaan tersebut.

Pada penelitian ini digunakan variabel kontrol yaitu size dan leverage untuk membuktikan bahwa good corporate governance mempunyai hubungan yang terikat dengan berbagai faktor. Hasilnya menunjukkan bahwa persamaan regresi hipotesis pertama menunjukkan terdapat pengaruh antara variabel kontrol size dengan kinerja keuangan perusahaan (ROE) dengan signifikansi sebesar 0,000 $<0,05$; namun tidak berpengaruh terhadap variabel kontrol leverage dengan kinerja keuangan perusahaan (ROE) dengan nilai signifikansi 0,521 > 0,05 . 


\section{b. Pengaruh GCG Terhadap Kinerja Keuangan Perusahaan (NPM)}

Hasil penelitian dari persamaan regresi untuk hipotesis pertama secara parsial dapat dikatakan bahwa analisa good corporate governance dalam penerapannya tidak memiliki pengaruh positif terhadap kinerja keuangan perusahaan (NPM). Hasil ini ditunjukkan dari hasil penelitian ini dimana menghasilkan suatu signifikansi 0,955 $>0,05$. Hasil ini menunjukkan bahwa terdapat faktor lain yang dapat mempengaruhi NPM misalnya perusahaan belum menyadari salah satu manfaat jangka panjang dengan menerapkan good corporate governance yang dapat menaikkan laba bersih suatu perusahaan. Dengan meningkatnya laba bersih suatu perusahaan, maka nilai saham dan nilai dividen secara bersama juga akan meningkat. Hal ini pun dapat meningkatkan minat para calon investor untuk menanamkan modal diperusahaan tersebut.

Pada penelitian ini digunakan variabel kontrol yaitu size dan leverage untuk menunjukkan bahwa good corporate governance dengan berbagai faktor mempunyai keterikatan. Hasilnya menunjukkan bahwa persamaan regresi hipotesis pertama menunjukkan terdapat pengaruh antara variabel kontrol size dengan kinerja keuangan perusahaan (NPM) dengan signifikansi sebesar 0,000 $<0,05$; namun tidak memiliki pengaruh antara variabel kontrol leverage dengan kinerja keuangan perusahaan (NPM) dengan signifikansi sebesar 0,521 >0,05.

\section{c. Pengaruh GCG Terhadap Kinerja Keuangan Perusahaan (EPS)}

Hasil dari persamaan regresi untuk hipotesis pertama secara parsial dapat dikatakan bahwa good corporate governance yang diterapkan memberikan pengaruh positif pada kinerja keuangan perusahaan (EPS). Hasil ini dibuktikan dari penelitian ini yang menghasilkan nilai signifikansi $0,015<0,05$. Hasil ini menunjukkan semakin baik penerapan good corporate governance suatu perusahaan maka semakin meningkatkan
EPS perusahaan tersebut. Nilai EPS yang tinggi akan menarik investor dalam berinvestasi, karena EPS yang tinggi dapat menghasilkan return saham yang tinggi pula bagi para investor.

Penelitian ini menggunakan variabel kontrol size dan leverage untuk menunjukkan bahwa good corporate governance mempunyai keterikatan dengan berbagai faktor. Hasilnya menunjukkan bahwa persamaan regresi hipotesis pertama menunjukkan terdapat pengaruh antara variabel kontrol size dengan kinerja keuangan perusahaan (EPS) dengan nilai signifikansi 0,784 > 0,05 ; namun tidak berpengaruh antara variabel kontrol leverage dengan kinerja keuangan perusahaan (EPS) dengan nilai signifikansi 0,081 >0,05.

\section{Kesimpulan}

Tata kelola perusahaan/Good corporate governance dalam penerapannya tidak memiliki pengaruh positif terhadap kinerja keuangan perusahaan yang diproksikan dengan Return on Equity (ROE). Dengan demikian, H1 ditolak.

Penerapan tata kelola perusahaan/good corporate governance tidak memiliki pengaruh positif pada kinerja keuangan perusahaan yang diproksikan dengan $\mathrm{Net}$ Profit Margin (NPM). Dengan demikian, H2 ditolak.

Penerapan tata kelola perusahaan/good corporate governance memiliki pengaruh positif pada kinerja keuangan perusahaan yang diproksikan dengan Earning's Per Share (EPS). Dengan demikian, H3 diterima.

\section{Daftar Pustaka}

[1] Priantara, D. Ketika Skandal Fraud Akuntansi Menerpa British Telecom dan PwC. Warta Ekonomi diakses dari https://www.wartaekonomi.co.id/ $\underline{(2017)}$

[2] Lestari, S. D., Wirawati, N. G. P.Good Corporate Governance sebagai Pemoderasi Pengaruh Asimetri Informasi pada Manajemen Laba. EJurnal Akuntansi Universitas Udayana. (2016) 
[3] Paradita, D. Pengaruh Good Corporate Governance terhadap Kinerja Keuangan pada Perusahaan yang Termasuk Kelompok Sepuluh Besar menurut Corporate Governance Perception Index (CGPI). Medan. (2009)

[4] Suparlim, R. Pengaruh Good Corporate Governance terhadap Kinerja Keuangan Perusahaan yang Terdaftar dalam Corporate Governance Perception Index (CGPI) Tahun 20072011. (2013)

[5] Ghozali, I. Ekonometrika : Teori, Konsep dan Aplikasi dengan SPSS 17.
Semarang: Universitas Diponegoro. (2011)

[6] Jumandani, R. Pengaruh Penerapan Good Corporate Governance terhadap Kinerja Keuangan Perusahaan. Skripsi. (2012)

[7] Kementrian Badan Usaha Milik Negara Republik Indonesia. Penerapan Praktek Good Corporate Governance Pada Badan Usaha Milik Negara (KEP100/MBU/2002). website Kementrian BUMN RI http://jdih.bumn.go.id/ (2017) 